\title{
Factors associated with death and readmission into the Intensive Care Unit ${ }^{1}$
}

\author{
Maria Claudia Moreira da Silva ${ }^{2}$ \\ Regina Marcia Cardoso de Sousa ${ }^{3}$ \\ Katia Grillo Padilha ${ }^{4}$
}

This study identifies the factors associated with death and readmission into the Intensive Care Unit. This is a longitudinal prospective study of 600 adult patients admitted in general Intensive Care Units of four hospitals in São Paulo, Brazil. The multiple regression analysis showed that patients with a longer length of stay and higher Nursing Activities Score, Simplified Acute Physiology Score II and Logistic Organ Dysfunction Score on the last day in the unit had a higher chance of death. Nevertheless, higher Nursing Activities Score and Logistic Organ Dysfunction Score on the first day in the intensive care unit were protective factors against death. Viral hepatitis as an antecedent increased the chance of readmission. On the other hand, higher Nursing Activities Score at discharge decreased this risk. It was concluded that the nursing workload was the main variable related to the outcomes analyzed.

Descriptors: Intensive Care Units; Death; Patient Readmission.

\footnotetext{
${ }^{1}$ Paper extracted from Doctoral Dissertation "Fatores relacionados com a alta, óbito e readmissão em Unidade de Terapia Intensiva", presented to Escola de Enfermagem, Universidade de São Paulo, SP, Brasil. Supported by Fundação de Amparo à Pesquisa do Estado de São Paulo (FAPESP), process \#2005/59667-8.

${ }^{2}$ RN, Ph.D. in Nursing. E-mail: mclaudiacontini@yahoo.com.br.

${ }^{3}$ RN, Ph.D. in Nursing, Associate Professor, Escola de Enfermagem, Universidade de São Paulo, SP, Brazil. E-mail: vian@usp.br.

${ }^{4}$ RN, Ph.D. in Nursing, Full Professor, Escola de Enfermagem, Universidade de São Paulo, SP, Brazil. E-mail: kgpadilh@usp.br.
}

Corresponding Author:

Regina Marcia Cardoso de Sousa

Universidade de São Paulo. Escola de Enfermagem.

Departamento Enfermagem Médico-Cirúrgica

Rua Dr. Enéas de Carvalho Aguiar, 419

Jardim Paulista

CEP: 05403-000, São Paulo, SP, Brasil

E-mail: vian@usp.br 


\section{Fatores associados ao óbito e a readmissão em Unidade de Terapia Intensiva}

O objetivo deste estudo foi identificar os fatores associados ao óbito e à readmissão dos pacientes em unidade de terapia intensiva. Estudo prospectivo longitudinal, com 600 pacientes adultos, internados em unidade de terapia intensiva geral de quatro hospitais do município de São Paulo. A análise de regressão múltipla mostrou que os pacientes com maior tempo de internação, Nursing Activities Score, Simplified Acute Physiology Score II e Logistic Organ Dysfunction Score mais elevados, no último dia de internação, tiveram mais chance de morrer, porém, as pontuações mais altas do Nursing Activities Score e Logistic Organ Dysfunction Score, na admissão, foram fatores protetores para óbito na unidade. Antecedente de hepatite viral aumentou a chance de readmissão; ao contrário, a maior pontuação do Nursing Activities Score, na alta, diminuiu esse risco. Concluiu-se que a carga de trabalho de enfermagem foi variável de destaque em relação aos desfechos analisados.

Descritores: Unidades de Terapia Intensiva; Morte; Readmissão do Paciente.

\section{Factores asociados a la muerte y a la readmisión en Unidad de Terapia Intensiva}

El objetivo de este estudio fue identificar los factores asociados con muerte y readmisión de pacientes en Unidad de Terapia Intensiva. Se trata de un estudio prospectivo longitudinal con 600 pacientes adultos, internados en Unidades de Terapia Intensiva general de cuatro hospitales del Municipio de Sao Paulo. El análisis de regresión múltiple mostró que los pacientes con mayor tiempo de internación, que tuvieron puntajes más elevados en: Nursing Activities Score, Simplified Acute Physiology Score II y Logistic Organ Dysfunction Score, en el último día de internación, tuvieron más probabilidad de morir; por otro lado las puntuaciones más altas del Nursing Activities Score y Logistic Organ Dysfunction Score, en la admisión, fueron factores protectores para muerte en la unidad. El antecedente de hepatitis viral aumentó la probabilidad de readmisión; al contrario, la mayor puntuación del Nursing Activities Score en el alta disminuyó ese riesgo. Se concluyó que la carga de trabajo de enfermería fue una variable destacada en relación a los resultados analizados.

Descriptores: Unidades de Terapia Intensiva; Muerte; Readmisión del Paciente.

\section{Introduction}

In recent decades, care standards at Intensive Care Units (ICUs) have evolved and intensive monitoring has become much more complex and diversified thanks to advanced technology. These conditions have increased the number of indications to ICUs, but the need to contain costs limits the expansion of the health system structure to permit care delivery to a larger number of patients at these units ${ }^{(1)}$. Thus, given the high cost of intensive care and the rising number of patients who demand specialized ICU care, it becomes fundamental to analyze these units' performance and identify factors related to unwanted outcomes, contributing to the optimization of bed use.

At ICUs, identifying patients at risk of death or rehospitalization can be of help in clinical care, permitting the adoption of measures in due time to reduce these events, with a view to preventive action involving these patients.

Intermediary care units, also called semi-intensive care, are an essential initiative to optimize the use and rationalize the number of ICU beds, so as to respond to the health system's high demand in specialized care. These 
units possess the structure to attend individuals who still need high-density nursing care and, thus, enhance the more economical and efficient use of space and services. In addition, as the most advanced intermediary care resources and non-invasive monitoring technology are readily available, a minority of patients need to stay at the ICU for monitoring purposes only, decreasing the pressures of the health system and society to expand beds at these units ${ }^{(2)}$.

Based on the above arguments, it was considered relevant to identify, at hospitals with intermediary units, factors related to deaths and ICU readmissions, with a view to recognizing risk groups for these events.

\section{Methods}

This prospective and longitudinal study involved adult patients hospitalized at general ICUs of two public and two private hospitals in São Paulo City.

The hospital selection was based on the following criteria: location in São Paulo City; more than 50 active beds; presence of general ICU and intermediary unit.

Criteria to exclude the hospitals were: exclusively pediatric clients; number of ICU beds less than $6 \%$ of all hospital beds; less than five beds at the intermediary unit(3).

In the DATASUS information base ${ }^{(4)}, 35$ general hospitals were identified in the city with more than 50 beds, which attended to adult clients and offered intensive care bed and intermediary units. In the analysis of the number of unit beds, 15 hospitals were excluded in view of the established criteria, resulting in 20 hospitals. Twelve of these were excluded after an on-site visit because they did not comply with the study criteria.

Among the eight remaining hospitals, those four institutions were selected with the largest number of intermediary unit beds. In this selection, public and private institutions were analyzed separately, maintaining two hospitals from each administrative sphere.

Six hundred patients aged $\geq 18$ tears were included, admitted at these ICUs between August 2006 and January 2007. A professional specialized in sampling calculate the sample, based on the research proposals and recent Brazilian literature data on ICU readmissions and mortality.

After approval from the Institutional Review Boards (Opinions No SMS52/2006; HU650/06; HSL2006/03 and $A E 06 / 510$ ) and previous contact with the nurses responsible for the ICUs, undergraduate nursing students started to collect data at the selected units, after training to collect the information of interest for the research.
Data were collected daily until completing 150 patients per hospital. Every day, the students attended the units to search for new patients and monitor others already included in the research.

All patients were monitored until discharge from hospital, so as to obtain data from the first and last 24 hours of stay at the ICU. After discharge from the ICU, patients were monitored at the unit until hospital discharge to identify possible readmissions. In those cases In case of multiple ICU readmissions, only the first was considered.

Data were treated in Stata for Windows 8.0 and SPSS 13.0 for Windows. Logistic regression was used to determine the factors associated with death and ICU readmission. In a first phase, univariate logistic regression was performed for each independent variable: age, gender, antecedents (classified according to the three-character list of the International Classification of Diseases - ICD-10(5) , origin, ICU hospitalization time, workload, measured by the Nursing Activities Score - NAS, death risk according to the Simplified Acute Physiology Score II - SAPS II and the Logistic Organ Dysfunction Score - LODS.

To construct the multiple logistic regression model, the stepwise forward method was used, in which variables with $\mathrm{p} \leq 0.20$ in univariate analysis were incorporated into the models one by one. Independent variables that reached $\mathrm{p}<0.05$ were maintained in the final model. The adequacy of the model was assessed through the Hosmer-Lemeshow test.

\section{Results}

As for demographic and clinical characteristics (Table 1), most patients were men (56.70\%) and elderly (53.34\%), coming from the Emergency Care unit (36.34\%) and Surgical Center (35.50\%). Among patients included in the category others, the large majority was forwarded from other hospitals, with 27 cases $(4.50 \%)$, while 9 patients $(1.50 \%)$ came from the procedure room.

The mean time of ICU stay was 8.90 ( \pm 10.90$)$ days, although it was observed that more than a quarter of patients (28.50\%) were hospitalized at the ICU for 10 days or more, $6.50 \%$ of whom remained at the unit for more than 30 days.

The most frequent category of antecedents was related to diseases of the circulatory apparatus (58.00\%), followed by endocrine, nutritional and metabolic diseases $(28.66 \%)$, tumors $(18.17 \%)$, diseases of the respiratory $(13.50 \%)$ and the genitourinary apparatus (13.00\%). 
The frequency of antecedents related to other ICD-10 categories corresponded to less than $10 \%$.

Table 1 - Demographic and clinical characteristics of patients ( $n=600)$. São Paulo, Brazil, 2006/2007

\begin{tabular}{|c|c|}
\hline Variable & $\mathbf{N}^{\circ}(\%)$ \\
\hline \multicolumn{2}{|l|}{ Age } \\
\hline$\geq 18$ and $<40$ & $92(15.33)$ \\
\hline$\geq 40$ and $<60$ & $188(31.33)$ \\
\hline$\geq 60$ and $<80$ & $215(35.84)$ \\
\hline$\geq 80$ & $105(17.50)$ \\
\hline Mean (Standard Deviation) & $60.68( \pm 18.79)$ years \\
\hline Variation & $18-97$ years \\
\hline Median & 61.50 years \\
\hline \multicolumn{2}{|l|}{ Gender } \\
\hline Male & $340(56.70)$ \\
\hline Female & $260(43.30)$ \\
\hline \multicolumn{2}{|l|}{ Origin } \\
\hline Hospitalization Unit & $55(9.17)$ \\
\hline Intermediary Unit & $68(11.33)$ \\
\hline Emergency Care Unit & $218(36.34)$ \\
\hline Surgical Center & $213(35.50)$ \\
\hline Others & $46(7.66)$ \\
\hline \multicolumn{2}{|l|}{ ICU Hospitalization Time } \\
\hline 1 to 2 days & $199(33.17)$ \\
\hline 3 to 9 days & $230(38.33)$ \\
\hline 10 to 29 days & $132(22.00)$ \\
\hline$\geq 30$ days & $39(6.50)$ \\
\hline Mean (Standard Deviation) & $8.90( \pm 10.90)$ days \\
\hline Variation & $1-79$ days \\
\hline Median & 5 days \\
\hline
\end{tabular}

The mean nursing workload upon admission to the ICU was $61.92 \%( \pm 21.57 \%)$, against $52.81 \%( \pm 15.85)$ on the last day of hospitalization at the unit. In the analysis of the mean NAS upon discharge or death, a considerable difference in this score stood out on the last ICU hospitalization day between patients who died and survived, respectively, 67.17\% ( \pm 17.47$)$ and 49.21 ( \pm 13.17$)$.

The mean death risk upon ICU admission was 25.50 ( \pm 22.12 ) according to the SAPS II and 21.43 ( \pm 18.66 ) according to the LODS, scores that approached the values found for patients upon discharge from the unit, with $23.14( \pm 23.88)$ and $20.73( \pm 21.30)$, respectively. Nevertheless, for patients who died, the mean SAPS II upon admission corresponded to 39.57 ( \pm 25.80 ), against $53.30( \pm 29.00)$ on the last day of hospitalization at the unit. When the LODS was applied, these scores amounted to $31.38( \pm 22.10)$ on the first ICU day and $47.60( \pm 26.26)$ on the day the patients died.

In this study, it was observed that $20.00 \%$ of patients died during their ICU stay. Among patients who survived $(n=480), 64.60 \%$ were discharged to intermediary units and $32.90 \%$ were transferred directly to the hospitalization unit. The percentage of patients readmitted to the ICU during the same hospitalization corresponded to $9.10 \%$.

Table 2 - Univariate logistic regression for the dependent variable condition upon discharge from ICU (death related to discharge). São Paulo, Brazil, 2006/2007

\begin{tabular}{|c|c|c|c|}
\hline Variables & Odds ratio (OR) & $95 \%$ confidence interval for OR & P-value \\
\hline Age range (reference $<60$ years) & 1.66 & $1.10-2.50$ & 0.016 \\
\hline Gender (Reference: Male) & 1.22 & $0.82-1.83$ & 0.323 \\
\hline \multicolumn{4}{|l|}{ Antecedents* (Reference: absence) } \\
\hline ICD10-I & 1.16 & $0.56-2.41$ & 0,699 \\
\hline ICD10-II & 1.22 & $0.74-2.01$ & 0,429 \\
\hline ICD10-III & 1.56 & $0.55-4.47$ & 0,406 \\
\hline ICD10-IV & 1.00 & $0.64-1.56$ & 1,000 \\
\hline ICD10-V & 0.60 & $0.26-1.36$ & 0,222 \\
\hline ICD10-VI & 0.84 & $0.36-1.95$ & 0,683 \\
\hline ICD10-IX & 0.83 & $0.55-1.24$ & 0,364 \\
\hline ICD10-X & 1.07 & $0.60-1.91$ & 0,811 \\
\hline ICD10-XI & 2.02 & $1.07-3.79$ & 0,029 \\
\hline ICD10-XII & 0.80 & $0.09-6.90$ & 0,838 \\
\hline ICD10-XIII & 3.24 & $1.18-8.89$ & 0,022 \\
\hline ICD10-XIV & 1.26 & $0.71-2.23$ & 0,428 \\
\hline ICD10-XVIII & 4.03 & $0.25-64.82$ & 0,326 \\
\hline ICD10-XIX & 0.56 & $0.13-2.52$ & 0,453 \\
\hline
\end{tabular}


Table 2 - (continuation)

\begin{tabular}{lccc}
\hline \multicolumn{1}{c}{ Variables } & Odds ratio (OR) & 95\% confidence interval for OR & P-value \\
\hline Origin (Reference: Hospitalization Unit) & & & \\
$\quad$ Intermediary Unit & 0.78 & $0.36-1.73$ & 0,546 \\
$\quad$ Surgical Center & 0.48 & $0.25-0.94$ & 0,033 \\
Emergency Care & 0.58 & $0.30-1.13$ & 0,110 \\
$\quad$ Others & 0.35 & $0.13-0.99$ & 0,047 \\
Hospitalization time (days) & 1.03 & $1.02-1.05$ & $<0.001$ \\
SAPSII admission (risk of death) & 1.03 & $1.02-1.04$ & $<0.001$ \\
LODS admission (risk of death) & 1.03 & $1.02-1.04$ & $<0.001$ \\
NAS admission & 1.01 & $1.00-1.02$ & 0.021 \\
SAPSII discharge/death (risk of death) & 1.07 & $1.06-1.09$ & $<0.001$ \\
LODS discharge/death (risk of death) & 1.08 & $1.07-1.10$ & $<0.001$ \\
NAS discharge/death & 1.08 & $1.06-1.10$ & $<0.001$ \\
\hline
\end{tabular}

*Excludes categories in which no patient presented a related disease or in which the outcome under analysis did not occur.

The results in Table 2 show that age range, time of ICU stay, SAPSII, LODS and NAS scores upon admission and on the last day of hospitalization at the unit, besides the presence of antecedents related to diseases of the digestive apparatus (ICD XI), of the musculoskeletal system and connective tissue (ICD XIII) showed to be associated with the discharge condition. The patient's origin from the Surgical Center and the sites included under the category others also showed a statistically significant association, but the odds ratio below one indicated that patients from these units showed a lesser change of death than patients coming from hospitalization units.

Table 3 - Multiple logistic regression model for condition upon discharge from ICU (death related to discharge). São Paulo, Brazil, 2006/2007

\begin{tabular}{|c|c|c|c|c|}
\hline Variable & $\begin{array}{c}\text { Non-adjusted } \\
\text { odds ratio (OR) }\end{array}$ & $\begin{array}{c}\text { Adjusted } \\
\text { odds ratio (OR) }\end{array}$ & $\begin{array}{c}95 \% \text { confidence } \\
\text { interval for OR }\end{array}$ & P-value \\
\hline NAS discharge / death & 1.08 & 1.08 & $1.06-1.11$ & $<0.001$ \\
\hline LODS discharge / death (death risk) & 1.08 & 1.06 & $1.04-1.09$ & $<0.001$ \\
\hline SAPSII discharge / death (death risk) & 1.07 & 1.05 & $1.03-1.07$ & $<0.001$ \\
\hline LODS admission (death risk) & 1.03 & 0.98 & $0.96-1.00$ & 0.030 \\
\hline Hospitalization time (days) & 1.03 & 1.03 & $1.01-1.06$ & 0.011 \\
\hline NAS admission & 1.01 & 0.97 & $0.96-0.99$ & 0.006 \\
\hline Hosmer-Lemeshow & $\chi^{2}=6.14$ & $p=0.6319$ & & \\
\hline
\end{tabular}

The results in Table 3 indicate that a one-point increase in SAPSII, LODS and NAS scores during the last 24 hours of ICU stay increased patients' chance of death by 5 to $8 \%$.

Regarding the hospitalization time, the logistic regression model shows that, for each additional day of ICU hospitalization, patients' chance of death increased by $3 \%$. It should be highlighted that general mortality amounted to $20 \%$, with $28.7 \%$ for patients who were hospitalized for 10 days or more and $38.5 \%$ among patients hospitalized $\geq 30$ days.
NAS and LODS scores upon admission, appointed as a death risk factor in univariate analysis, when studied jointly with other variables, modified their behavior towards the response variable. Thus, patients with the highest SAPSII, LODS and NAS scores upon discharge/ death and the longest ICU hospitalization time showed a lesser chance of death when NAS and LODS scores upon admission were higher.

The assessment of the model's adequacy according to the Hosmer-Lemeshow test showed that the logistic regression model was adequately adjusted, with $p=0.6319$. 
Table 4 - Univariate logistic regression for the dependent variable ICU readmission of patient. São Paulo, Brazil, $2006 / 2007$

\begin{tabular}{|c|c|c|c|}
\hline Variable & Odds ratio (OR) & $95 \%$ confidence interval for OR & P-value \\
\hline Age range (Reference:<60 years) & 0.99 & $0.53-1.88$ & 0.984 \\
\hline Gender (Reference: Male) & 1.03 & $0.54-1.94$ & 0.937 \\
\hline \multicolumn{4}{|l|}{ Antecedents (Reference: absence) } \\
\hline ICD10-I & 2.85 & $1.18-6.88$ & 0.019 \\
\hline ICD10-II & 0.74 & $0.30-1.79$ & 0.499 \\
\hline ICD10-III & 4.47 & $1.39-14.38$ & 0.012 \\
\hline ICD10-IV & 1.65 & $0.86-3.17$ & 0.136 \\
\hline ICD10-V & 1.49 & $0.56-3.97$ & 0.429 \\
\hline ICD10-VI & 0.69 & $0.16-2.97$ & 0,619 \\
\hline ICD10-VII & 3.41 & $0.37-31.25$ & 0,277 \\
\hline ICD10-IX & 0.82 & $0.43-1.55$ & 0,541 \\
\hline ICD10-X & 1.87 & $0.86-4.07$ & 0,117 \\
\hline ICD10-XI & 1.60 & $0.60-4.28$ & 0,351 \\
\hline ICD10-XIV & 1.72 & $0.76-3.87$ & 0,192 \\
\hline ICD10-XIX & 1.96 & $0.43-8.95$ & 0,383 \\
\hline \multicolumn{4}{|l|}{ Origin (Reference: Intermediary Unit) } \\
\hline Intermediary Unit & 1.01 & $0.26-3.96$ & 0,986 \\
\hline Surgical Center & 1.13 & $0.37-3.52$ & 0,827 \\
\hline Emergency Care & 0.69 & $0.21-2.28$ & 0,546 \\
\hline Others & 1.21 & $0.29-5.15$ & 0,792 \\
\hline Hospitalization time (days) & 0,98 & $0.94-1.01$ & 0.214 \\
\hline SAPSII admission (death risk) & 1,00 & $0.99-1.02$ & 0.514 \\
\hline LODS admission (death risk) & 1,01 & $1.00-1.03$ & 0.132 \\
\hline NAS admission & 1,00 & $1.00-1.02$ & 0.919 \\
\hline SAPSII discharge (death risk) & 0,99 & $0.98-1.01$ & 0.429 \\
\hline LODS discharge (death risk) & 1,00 & $0.98-1.01$ & 0.760 \\
\hline NAS discharge & 0,98 & $0.96-1.00$ & 0.042 \\
\hline
\end{tabular}

* Excludes categories in which no patient presented a related disease or in which the outcome under analysis did not occur.

Table 4 shows that, among independent variables, only NAS upon discharge and the presence of antecedents related to infectious and parasitic diseases (ICD I) and Diseases of the blood and blood-forming organs and certain disorders involving the immune mechanism
(ICD III) showed to be associated with ICU readmission. The odds ratio for NAS upon discharge shows that the increase in this indicator's score decreased the chance of patients' readmission to the ICUs.

Table 5 - Multiple logistic regression model for patient readmission to ICU. São Paulo, 2006/2007

\begin{tabular}{|c|c|c|c|c|}
\hline Variable & Non-adjusted odds ratio (OR) & Adjusted odds ratio (OR) & $95 \%$ confidence interval for OR & P-value \\
\hline ICD10-I & 2.85 & 2.97 & $1.23-7.22$ & 0.016 \\
\hline NAS discharge & 0.98 & 0.98 & $0.95-1.00$ & 0.036 \\
\hline Hosmer-Lemeshow & $\chi^{2}=5.10$ & $p=0.7470$ & & \\
\hline
\end{tabular}

The regression model presented in Table 5 shows that the risk of ICU readmission as almost three times higher among patients with some infectious and parasitic diseases included in ICD group I, in comparison with patients without this type of antecedents. The analysis of 45 patients with antecedents related to this type of disease shows that the most frequent diseases were hepatitis, AIDS and Chagas' disease, indicated in 25 $(4.17 \%), 6(1.00 \%)$ and $5(0.83 \%)$ cases, respectively. Among the 45 patients with antecedents related to ICD10 group I, seven (15.80\%) were readmitted, six of whom suffered from viral hepatitis and one from Chagas' disease. 
The odds ratio indicated that the NAS upon discharge served as a protective factor for the readmission condition, that is, a one-point increase in the NAS score upon discharge reduced the risk of ICU readmission by $2 \%$.

The result of the Hosmer-Lemeshow test also indicated good adequacy of the regression model $(p=0.7470)$.

\section{Discussion}

The analysis of the demographic and clinical characteristics showed that the study participants' age, gender, origin and antecedents was in line with previous descriptions in Brazilian and international literature ${ }^{(6-10)}$.

Out of 600 patients analyzed, 20.00\% died during their ICU stay, a higher mortality rate in comparison with some foreign and Brazilian studies ${ }^{(7-8,11)}$, but lower than in other studies ${ }^{(6,12-14)}$.

In the sample, it was verified that about $9 \%$ of patients were readmitted to the ICU before hospital discharge, a higher percentage than the mean $7.78 \%$ in a recently published literature review ${ }^{(15)}$, but lower than the percentage observed at a private institution in São Paulo City $(10.7 \%)^{(16)}$.

Regarding the factors related to death at the ICU, it was observed that patients who died obtained higher SAPS II, LODS and NAS scores on the last day of ICU hospitalization.

Also, in comparison with survivors, patients who died also showed higher NAS on the last day of ICU hospitalization. The worsening of patients who died, in comparison with the clinical improvement of patients discharged must have contributed to the difference observed among the nursing workloads for these patients. In addition, the increase in administrative tasks and demand for support to relatives, inherent in the situation of patient death, also contributed to this result.

Literature results also reinforce the NAS and mortality relation. Studies show that patients who worsen and evolve to death demand longer nursing work time ${ }^{(6-7,13-14,17)}$.

Patient mortality reached about $40 \%$ in patients hospitalized at the ICU for 30 days or more. In general, patients who stayed longer at the ICU are in more unstable conditions or present complications deriving from their disease or invasive procedures.

As for ICU hospitalization time, patient follow-up studies have shown that a close relation exists between prolonged ICU hospitalization time and greater nursing workload, besides patient severity ${ }^{(7,13)}$.

Differently from results obtained on the last day of ICU hospitalization, high LODS and NAS scores on the first day at the unit served as a protection factor for patients: individuals with enhanced organic dysfunction and who consumed more nursing work time upon ICU admission survived more frequently. These patients' greater death risk may have increased the medical team's clinical care, just like the longer nursing care time, as early as on the first day of ICU hospitalization, may have contributed to decrease this group's mortality.

This result can also be related to the high frequency of patients from the Surgical Center in the study sample $(35.50 \%)$, with a lesser chance of dying than patients coming from hospitalization units (Table 2) and the high demand for immediate postoperative nursing care. A study that analyzed predictors of nursing care demands for elderly people showed that surgical patients hospitalized at ICUs demand more nursing care time in comparison with patients hospitalized for clinical problems $^{(10)}$.

Regarding ICU readmission, the results showed antecedents related to ICD-10 categories I and III as independent factors. The presence of co-morbidities has already been associated with ICU readmission in other studies $^{(18-19)}$. In addition, clinical practice has shown that acute alterations patients present can exacerbate chronic illnesses.

Viral hepatitis stood out in the association between readmission and antecedents related to infectious and parasitic diseases (category I - ICD-10), increasing the chance of this event, while the highest NAS scores upon discharge from the ICU served as a protection factor for patient readmission to this unit.

Co-morbidities associated with ICU readmission include cirrhosis and liver failure ${ }^{(19)}$. Besides, a study that included 10,840 patients hospitalized at a surgical intensive care unit during a five-year period, at a level I trauma center and multiple organ transplantation center of a teaching hospital, showed that liver transplanted patients presented higher readmission frequencies $(7.2 \%)$ in comparison with the total patient group $(2.73 \%)$. For the authors of that research, this result was not surprising, as liver transplanted patients tend to be in more severe conditions than other surgical patients and can develop life-threatening sequelae, demanding intense observation and additional procedures ${ }^{(20)}$. Although these study results do not directly appoint viral 
hepatitis as a risk factor for readmission, they evidence liver alterations in the occurrence of this event.

The potential risk factors for ICU readmission mentioned in literature are countless and varying. Some of these factors were not confirmed in the current sample, such as male gender ${ }^{(21)}$, age ${ }^{(21-22)}$, origin ${ }^{(23)}$, initial severity of the disease ${ }^{(22)}$ and ICU hospitalization time(23). Others, however, were not focused on in this research, such as hospitalization time before ICU admission ${ }^{(22)}$ and postoperative care needed(24). Other authors who analyze ICU readmission have also appointed difficulties to make comparisons and identify common predictors ${ }^{(15,18,22)}$.

A range of methodological approaches and data treatment forms contribute to this differences, but particularities among hospitals and mainly among countries, with different clients and health care organization systems, probably also affect the characteristics of the readmissions under analysis.

In that sense, it should be highlighted that nursing care needs for a complex respiratory failure predicted readmission and unexpected death in a study of patients hospitalized at an American and Dutch tertiary care center(23).

The nursing workload is a variable that had not been directly studied yet in analyses of ICU readmissions. European authors, however, using the Therapeutic Intervention Scoring System-28 (TISS-28), showed that readmitted patients need a significantly higher care level on the first and last ICU day(21).

The NAS is the instrument that resulted from the improvement of the TISS-28, from a nursing workload estimation perspective. Thus, the present research results, differently from previous studies' signs(21,23), point towards a relation between higher nursing workload upon discharge from the ICU and lower risk of patient readmission to the unit. This observation may be related with enhanced patient surveillance after ICU discharge, but this statistical finding should be further explored in other Brazilian studies.

Although the researchers attempted to guarantee an adequate number of beds in the selection criteria for participating hospitals, it should be mentioned that ICU admission and discharge decisions can involve structural factors, such as: lack of available ICU, intermediary unit and hospitalization beds, inadequate nurse/patient relation or other factors, including cost-related ones, not analyzed in this study.

\section{Conclusion}

In summary, the present study results offer evidence that differences exist in the characteristics of patients who die, survive or are readmitted to the ICU. The nursing workload (NAS) is the paramount variable for these outcomes.

The role of the nursing workload for the death and ICU readmission outcome evidences the importance of nurses' work at these units and signals that, in the discussion about the patient's discharge, improvements in the patient's clinical condition are not enough. The nursing workload the patient demands also needs to be taken into account.

\section{References}

1. Miranda DR, de Rijk A, Schaufeli W. Simplified Therapeutic Intervention Scoring System: the TISS-28 items: results from a multicenter study. Crit Care Med. 1996;24(1):64-73.

2. Cullen DJ, Nemeskal AR, Zaslavsky AM. Intermediate TISS: a new therapeutic Intervention Scoring System for non-ICU patients. Crit Care Med. 1994;22(9):1406-11.

3. Ministério da Saúde (BR). Secretaria de Vigilância Sanitária. Regulamento Técnico para o funcionamento dos serviços de tratamento intensivo. Portaria no 466, de 04 de junho de 1998. Brasília (DF); 1998.

4. Ministério da Saúde (BR). DATASUS. Indicadores: leitos. [acesso 28 set 2005]. Disponível em: http:// cnes.datasus.gov.br/Mod_Ind_Tipo_Leito.asp.

5. Organização Mundial da Saúde (OMS). CID -10. Classificação estatística internacional de doenças e problemas relacionados à saúde. $3^{a}$ ed. São Paulo: OMS; 1996. v. 3.

6. Silva MCM, Sousa RMC. Caracterização dos pacientes adultos e adolescentes das unidades de terapia intensiva do Município de São Paulo. Rev Paul Enferm. 2002;21(1):50-9.

7. Gonçalves LA, Padilha KG. Fatores associados à carga de trabalho de enfermagem em unidade de terapia intensiva. Rev Esc Enferm USP. 2007;41(4):645-52.

8. Ducci AJ, Padilha KG. Nursing Activities Score (NAS): a comparative study about retrospective and prospective applications in intensive care units. Acta Paul Enferm. 2008;21(4):581-7. 
9. Bastos PG, Sun X, Wagner DP, Knaus WA, Zimmerman JE. Application of the APACHE III prognostic system in Brazylian intensive care units: a prospective multicenter study. Intensive Care Med. 1996;22(6):564-70.

10. Sousa CR, Gonçalves LA, Toffoleto MC, Leão $K$, Padilha KG. Predictors of nursing workload in elderly patients admitted to intensive care units. Rev. Latino-Am. Enfermagem. 2008;16(2):218-23. Inglês, Português, Espanhol.

11. Beck DH, Smith GB, Pappachan JV, Millar B. External validation of the SAPS II, APACHE II and APACHE III prognostic models in South England: a multicentre study. Intensive Care Med. 2003;29:249-56.

12. Padilha KG, Sousa RMC, Kimura M, Miyadahira AMK, Cruz DALM, Vattimo MF, et al. Nursing workload in intensive care units: a study using the Therapeutic Intervention Scoring System-28 (TISS-28). Intensive Crit Care Nurs. 2007;23(3):162-9.

13. Timsit JF, Fosse JF, Troché G, Lassence A, Alberti C, Garrouste-Orgeas $M$, et al. Calibration and discrimination by daily Logistic Organ Dysfunction Scoring comparatively with daily Sequential Organ Failure Assessment scoring for predicting hospital mortality in critically ill patients. Crit Care Med. 2002;30(9):2003-13.

14. Ducci AJ, Padilha KG, Telles SCR, Gutierrez BAO. Gravidade de pacientes e demanda de trabalho de enfermagem em Unidade de Terapia Intensiva: análise evolutiva segundo o TISS-28. Rev Bras Ter Intensiva. 2004;16(1)22-7.

15. Elliott M. Readmission to intensive care: a review of the literature. Aust Crit Care. 2006;19(3):96-104.

16. Moura DF Junior. Fatores de risco para readmissão em terapia intensiva [dissertação]. São Paulo (SP): Escola Paulista de Medicina, Universidade Federal de São Paulo; 2004.

17. Padilha KG, Sousa RMC, Queijo AF, Mendes AM, Miranda DR. Nursing activities score in the intensive care unit: analysis of related factors. Intensive Crit Care Nurs. 2008;24(3):197-204.

18. Rosenberg AL, Hofer TP, Hayward RA, Strachan C, Watts CM. Who bounces back? Physiologic and other predictors of intensive care unit readmission. Crit Care Med. $2001 ; 29(3): 511-8$.

19. Cooper GS, Sirio CA, Rotondi AJ, Shepardson LB, Rosenthal GE. Are readmissions to the intensive care unit a useful measure of hospital performance? Med Care. 1999;37(4):399-408.
20. Alban RF, Nisim AA, Ho J, Nishi GK, Shabot MM. Readmission to surgical intensive care increases severity-adjusted patent mortality. J Trauma. 2006;60(5): 1027-31.

21. Metnitz PG, Fieux F, Jordan B, Lang T, Moreno R, Gall JR. Critically ill patients readmitted to intensive care units: lessons to learn? Intensive Care Med. 2003;29(2):241-8.

22. Campbell AJ, Cook JA, Cuthbertson BH. Predicting death and readmission after intensive care discharge. $\mathrm{Br}$ J Anaesth. 2008;100(5):656-62.

23. Gajic O, Malinchoc M, Comfere TB, Harris M, Achouiti $A$, Yilmaz $M$ et al. The stability and Workload Index for Transfer score predicts unplanned intensive care unit patient readmission: initial development and validation. Crit Care Med. 2008;36(3):676-82.

24. Russell S. Reducing readmissions to the intensive care unit. Heart Lung. 1999;28(5):365-72.
Received: Apr. $2^{\text {nd }} 2010$ Accepted: Dec. $10^{\text {th }} 2011$ 